\title{
IMMUNOHISTOCHEMICAL EXPRESSION OF KI-67 IN ODONTOGENIC KERATOCYST: EVIDENCE OF AGGRESSIVE BEHAVIOR.
}

1. BDS, M. Phil Oral Pathology Demonstrator/ Lecturer de 'Montmorency College of Dentistry Lahore.

2. BDS, M. Phil Oral Pathology Assistant Professor Azhra Naheed dental College, Lahore.

3. MBBS, PhD, FCPS, FCPP, FRCP, FRC PATH

Professor

Department of Pathology

University of Health Sciences, Lahore.

4. MBBS, M. Phil., PhD

Professor

Department of Pathology

University of Health Sciences, Lahore.

5. BDS, M. Phil Oral Pathology, Ph.D scholar

Associate Professor

de'Montmorency College of

Dentistry Lahore.

6. BDS, M. Phil Oral Pathology. M. Phi Public Health

Demonstrator/ Lecturer de'Montmorency College of Dentistry Lahore.

Correspondence Address:

Dr. Rabiya Saif

Department of Pathology

de 'Montmorency College of Dentistry Lahore.

rabiyamajid25@gmail.com

Article received on:

25/02/2019

Accepted for publication:

01/10/2019

\section{INTRODUCTION}

Odontogenic keratocysts (OKC) are common and clinically aggressive lesions which arise from dental lamina or rest of Serres. ${ }^{1}$ OKC have mandibular predominance with a predilection for the posterior body and ramus regions followed by anterior mandible. In the maxilla, these occur most commonly in the third molar area followed by cuspid region. ${ }^{2}$ Odontogenic keratocysts may be found in all ages ranging from infancy to old age, but about $60 \%$ of all cases are diagnosed in first four decades of life. There is a slight male predominance. ${ }^{3}$ World Health Organization (WHO) recommended the term keratocystic odontogenic tumour (KOT) depicting its neoplastic nature in year $2005 .{ }^{4}$

\begin{abstract}
Rabiya Saif', Hafiz Majid Jehangir ${ }^{2}$, Abdul Hannan Nagi ${ }^{3}$, Nadia Naseem ${ }^{4}$, Zainab Rizvi ${ }^{5}$, Faiz Rasul ${ }^{6}$ laborath $(\mathrm{IHC})$ with $\mathrm{Ki}-67$ antibody was performed. Immunohistochemical scoring was done on the basis of percentage of the nuclear staining of Ki-67. Data was entered into SPSS 22 and descriptive also observed in few cases.

Key words:

Immunohistochemistry, Ki-67, Odontogenic Keratocysts.

Jehangir HM, Nagi AH, Naseem - N, Rizvi Z, Rasul F. mmunohistochemical expression of ki-67 in odontogenic keratocyst: Evidence of aggressive behavior. Professional Med J 2020; 27(1):74-79. DOI: 10.29309/TPMJ/2020.27.1.3317
\end{abstract}

The Ki-67 protein (also known as MKI67) is a marker for cellular proliferation. ${ }^{5}$ It has been described that Ki-67 antigen expression rises in pre-malignant and malignant lesions of the oral mucosa, and in all conditions of high cell turnover. MIB-1 (monoclonal antibody) reacts with the epitope of the Ki-67 nuclear antigen in formalin-fixed, paraffin-embedded sections. ${ }^{6} \mathrm{Ki}-$ 67 is commonly used to evaluate the proliferative activity in neoplastic and non-neoplastic lesions, including odontogenic cysts. ${ }^{7}$ The purpose of this study was to determine immunohistochemical expression of $\mathrm{Ki}-67$ in odontogenic keratocysts that will help in assessing the proliferative potential in these cysts. 


\section{MATERIALS \& METHODS}

This descriptive study was conducted in the department of Oral Pathology at University of Health Sciences, Lahore after the approval of institutional review board. A total of 39 diagnosed cases of OKC were collected after written and verbal consent of the respondents, those who did not give consent were excluded from the study. Samples were taken from de 'Montmorency College of dentistry, Lahore. Patients both genders of all ages were included in the study. Patients having history of associated debilitating chronic co-morbid conditions like uncontrolled diabetes mellitus, tuberculosis, malignancies, patients with immune disorders, with recurrence of cysts or tumor and inadequate tissue sample were also excluded from the study.

Labelled specimens after being fixed in formal-saline were brought to the department of Histopathology, UHS, where they were allocated a specific laboratory number. After gross examination, tissues were processed for preparing paraffin blocks. Paraffin embedded sections were prepared.

Histopathological diagnosis under Hematoxylin and Eosin was also confirmed. The sections were stained with monoclonal mouse anti-Human $\mathrm{Ki}$ 67 Antigen Clone MIB-1 Code M7240 (DAKO) and examined to assess the proliferative index. The percentage of positive nuclear staining of epithelial cells in 10 high-power field (40X) was used to classify each cystic lesion, using the following criteria; negative ( $<5 \%$ cells positive), low expression (5\%-50\% cells positive) and high expression ( $>50 \%$ cells positive).

The data was entered in SPSS 22. Quantitative variables such as age of patient, size of the cyst, and Ki-67 score were calculated with mean (+ S.D). Frequencies, percentages and graphs were given for qualitative variables like gender, and site of the cyst. $P$ value $<0.05$ was taken as significant.

\section{RESULTS}

The mean age of the patients was $25.08 \pm 14.5$ years. The age of patients was divided into two groups: $\leq 25$ years of age and $>25$ years with $\mathrm{n}=21(54 \%)$ patients falling in first group and $\mathrm{n}=18$ $(46 \%)$ in the latter group. Painless swelling was the most frequently reported symptom $(61.5 \%)$. Radio graphically, $69.2 \%$ of OKCs were $<2 \mathrm{~cm}$ in diameter, $23.1 \%$ were $2-4 \mathrm{~cm}$ in diameter while only $7.7 \%$ were $>4 \mathrm{~cm}$ in diameter.

Posterior mandible was the commonest site $(61.5 \%)$ and $92.3 \%$ of the cysts were unilocular. On histopathological examination, following observations were made shown in Table-I.

Age of the patients ( $p$ value $=0.004$ ) and site of specimen ( $p$ value $=0.003$ ) showed significance with the occurrence of OKC in these patients.

Photomicrograph 1-4 depicting characteristics of histopathology and ki-67 expression in OKC. When histological variables were related with odontogenic keratocyst (cross tabulation), parakeratinized epithelial lining $(p=0.00)$, epithelial hyperplasia both typical and atypical $(p=0.02)$ and focal spongiosis $(p=0.04)$ demonstrated significant association.

Foci having epithelial atypia demonstrated stronger staining intensity compared to adjacent normal epithelium. However, no significant association was observed between the histological variables and Ki-67 ( $p=0.08)$.

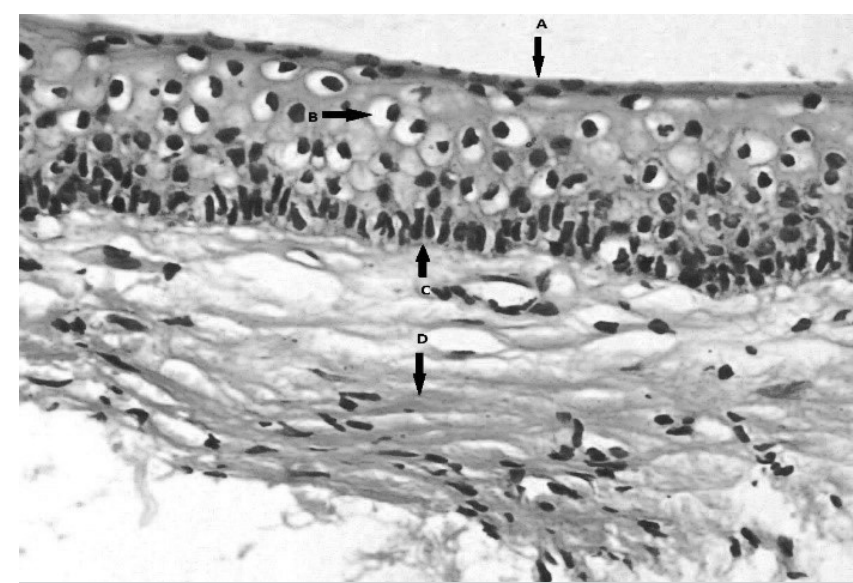

Photomicrograph-1. of OKC showing parakeratinized epithial lining (A), cytoplasmic vesiculation (B), palisaded basal layer (C), fibrous connective tissue (D) 

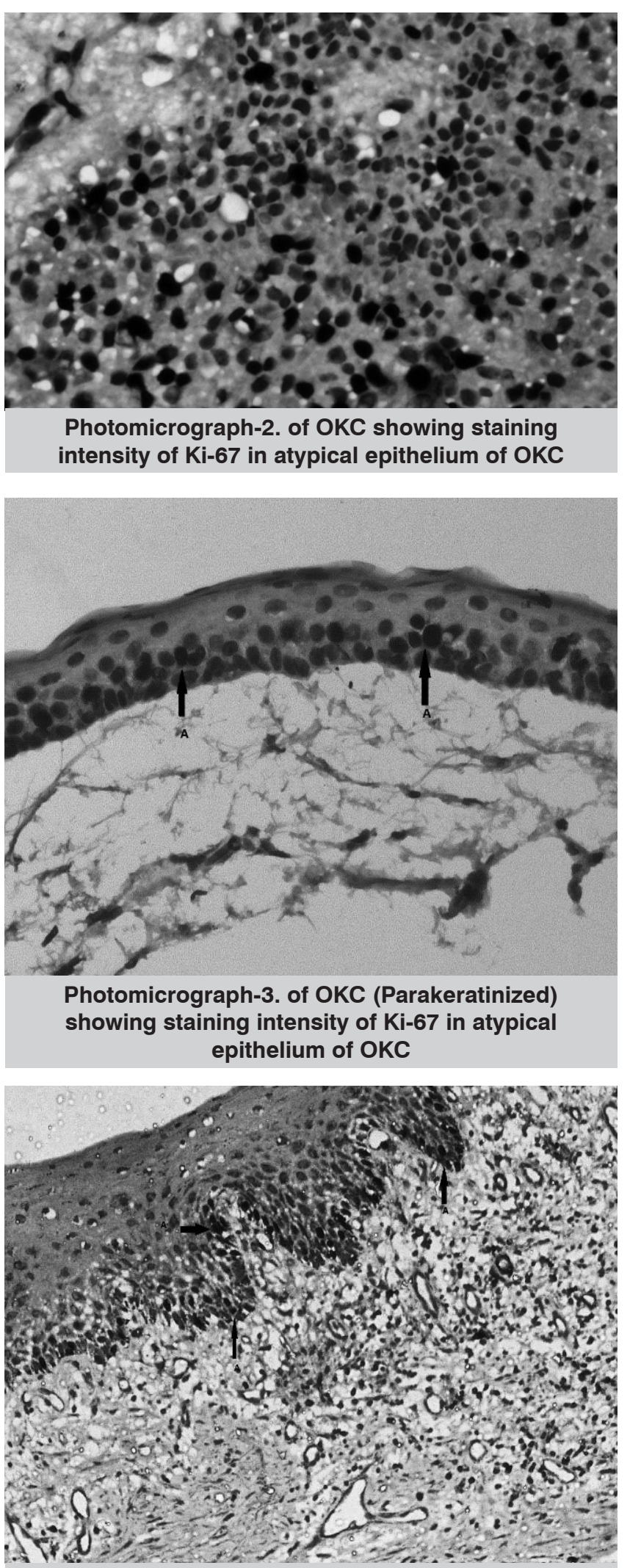

Photomicrograph-4. of OKC showing staining intensity of Ki-67 in atypical epithelium of OKC

\begin{tabular}{|c|c|c|}
\hline $\begin{array}{l}\text { Serial } \\
\text { Number }\end{array}$ & Variables & Frequency \\
\hline \multirow{5}{*}{$\begin{array}{l}\text { Clinical } \\
\text { Features }\end{array}$} & $\begin{array}{l}\text { Age } \\
<25 \\
>25\end{array}$ & $\begin{array}{l}54 \% \\
46 \%\end{array}$ \\
\hline & $\begin{array}{l}\text { Gender } \\
\text { Male } \\
\text { Female }\end{array}$ & $\begin{array}{l}66.6 \% \\
33.4 \%\end{array}$ \\
\hline & Asymptomatic swelling & $61.5 \%$ \\
\hline & $\begin{array}{l}\text { Site: } \\
\text { Anterior, } \\
\text { Posterior }\end{array}$ & $\begin{array}{l}38.5 \% \\
61.5 \%\end{array}$ \\
\hline & $\begin{array}{l}\text { Size } \\
<2 \mathrm{~cm} \text { in diameter, } \\
2-4 \mathrm{~cm} \text { in diameter } \\
>4 \mathrm{~cm} \text { in diameter }\end{array}$ & $\begin{array}{c}69.2 \% \\
23.1 \% \\
7.7 \%\end{array}$ \\
\hline Radiographic & $\begin{array}{l}\text { Unilocular } \\
\text { Multilocular }\end{array}$ & $\begin{array}{l}92.3 \% \\
7.7 \%\end{array}$ \\
\hline \multirow{16}{*}{$\begin{array}{l}\text { Histo- } \\
\text { pathological } \\
\text { Chara- } \\
\text { cteristics of } \\
\text { OKC on H\&E }\end{array}$} & Parakeratinized & $61.5 \%$ \\
\hline & Orthokeratinized & $30.8 \%$ \\
\hline & Epithelial Hyperplasia & $38.5 \%$ \\
\hline & Keratinocytic spongiosis & $46.2 \%$ \\
\hline & Acantholysis & $7.7 \%$ \\
\hline & Epithelial atypia & $84.6 \%$ \\
\hline & $\begin{array}{l}\text { Nuclear pleomorphism } \\
\text { (mild) }\end{array}$ & $76.9 \%$ \\
\hline & Prominent nucleoli & $46.2 \%$ \\
\hline & \multicolumn{2}{|c|}{ Inflammation in Connective Tissue } \\
\hline & Mild & $30.8 \%$ \\
\hline & Moderate & $53.8 \%$ \\
\hline & Severe & $15.4 \%$ \\
\hline & \multicolumn{2}{|c|}{ Connective Tissue Changes } \\
\hline & Hyalinization & $15.4 \%$ \\
\hline & Fibroplasia & $76.9 \%$ \\
\hline & Fibrosis & 7.7 \\
\hline \multirow{4}{*}{$\begin{array}{l}\text { Ki-67 } \\
\text { Expression in } \\
\text { OKC }\end{array}$} & Score of Ki-67 & Percentage \\
\hline & Negative & $15.4 \%$ \\
\hline & Low Expression & $76.9 \%$ \\
\hline & High expression & 7.7 \\
\hline \multirow{3}{*}{$\begin{array}{l}\text { Association } \\
\text { of OKC with } \\
\text { variables }\end{array}$} & OKC & $P$ value \\
\hline & Age category $<25,>25$ & 0.004 \\
\hline & Site anterior, posterior & 0.003 \\
\hline
\end{tabular}

Professional Med J 2020;27(1):74-79.

www.theprofesional.com 


\section{DISCUSSION}

Odontogenic keratocysts in the present study were most common in third decade of life which is similar to the results of study conducted by Selvamani et $a l^{8}$ (2012) but shows variation from a study conducted by Ansari et $\mathrm{al}^{9}$ (2010) who reported OKC to be prevalent in $2^{\text {nd }}$ decade of life. Although sample size is limited yet male predominance was seen in the present study (M: $\mathrm{F}$ ratio $=2: 1$ ) which is concordant with the results of study conducted by Ansari et $\mathrm{al}^{9}$ (2010) (M: $\mathrm{F}=2: 1)$ and Selvamani et $\mathrm{al}{ }^{8}$ (2012) (M: $\mathrm{F}=1.2: 1$ ). Posterior mandible was the most common site of occurrence for OKCs (61.5\%) in the present study which is consistent with the studies conducted by Ansari et $\mathrm{al}^{9}$ (2010) and Selvamani et al ${ }^{8}$ (2012) as $76 \%$ and $37.5 \%$ cases of OKCs involved mandible respectively.

When size of OKCs was observed radio graphically, a total of $69 \%$ OKCs were $<2 \mathrm{~cm}$ in diameter which is discordant with an Israelian study conducted in $2012^{10}$ which reported $>2 \mathrm{~cm}$ as the mean diameter of Odontogenic keratocysts. A total of $95 \%$ of OKCs were unilocular in the present study which is concordant with the study conducted by Jankowski et $\mathrm{al}^{11}$ but this finding was not supported by another study conducted in Pakistan by Khan et al $(2009)^{12}$ which showed that $83 \%$ odontogenic keratocysts were multilocular while only $17 \%$ were unilocular his is might be due to diverse biological behavior of the lesion.

Histologically most cases of OKCs (61\%) were lined by parakeratinised epithelium which is similar to the findings of most of the studies conducted in different countries. ${ }^{13,14}$ Epithelial hyperplasia was observed in $38.5 \%$ OKCs in the present study which is consistent with a study conducted on the Brazilian population. ${ }^{15}$ Spongiosis was observed in $46 \%$ OKCs in the present study but no data is available in the literature regarding spongiosis in OKCs. Epithelial atypia comprising of increased nuclear to cytoplasmic ratio, prominent nucleoli and nuclear pleomorphism was observed in $84.6 \%$ OKCs in the present study but data is scanty in the literature in this context. Chronic inflammation was observed in connective tissue of $76.9 \%$ OKCs and it was of moderate severity
(53.8\%) in most of OKCs. Finding of the present study is consistent with the study of Kwon et al ${ }^{16}$ and Nadalin et $\mathrm{al}^{17}$ who also reported chronic inflammation in OKCs but Nadalin et $\mathrm{al}^{17}$ reported severe inflammation in connective tissue of OKC. Fibroplasia was present in $85 \%$ OKCs and vascular congestion was observed in only $15.4 \%$ OKCs but data in literature is not available regarding these both variables.

Immunohistochemical staining with Ki-67 showed low expression in $76.9 \%$ OKCs, negative expression in $15.4 \%$ while high expression was observed in only $7.7 \%$ OKCs in the present study. The present study is discordant with the study of Nadalinet al $^{17}$ in that low Ki-67 expression was demonstrated by $94 \%$ OKCs in this study. The present study is quite comparable with the study conducted by Wahbaet $\mathrm{al}^{18}$ who reported that $80 \%$ OKCs showed moderate staining with Ki-67.

Ki-67 was positive in $84.6 \%$ OKCs in the present study and foci showing epithelial atypia demonstrated stronger intensity of $\mathrm{Ki}$ 67 immunostaining which might predict some strong link with the development of preneoplastic changes as it has not yet been mentioned in the literature related to odontogenic cysts. However, Humayun and Prasad $^{19}$ reported a significant correlation between progression of oral epithelium from normal to neoplastic and increased expression of Ki-67 antigen suggesting it to be a useful biomarker of malignant transformation in oral premalignant conditions. Therefore epithelial hyper proliferation is considered to be an early indicator of disorganized growth.

MCM-2 is more sensitive marker as compared to $\mathrm{Ki}-67$ in order to assess proliferation and growth rate, although all cases of OKC expressed expression of Ki-67 but intensity is lesser than MCM-2 concluded by Acharya et al (2019)..$^{20}$ Recently in $4^{\text {th }}$ edition of WHO classification of odontogenic tumor (2017), OKC is placed back into the category of odontogenic cysts, due to insufficient evidence regarding mutation of $\mathrm{PTCH}$ gene, furthermore Orthokeratinized OKC (OOKC) is declared as separate cyst as previously it was consider as variant of OKC. There are many 
reasons due to which it is declared as a separate cyst such as lack of palisading, less aggressive behavior and less recurrent rate ${ }^{21}$ however still controversy exists. ${ }^{22}$

\section{LIMITATIONS}

Lastly, this study has some limitations such as limited sample size and lack of clinic pathological correlations. Further studies with large sample size and cyst with relative early diagnosis are recommended to measure proliferative behavior of this odontogenic cyst There is also need to compare proliferative potential in OKCs which have early diagnostic history (short duration of diseases) as compared to long standing history (long duration of cyst).

\section{CONCLUSION}

Ki 67 expression (labelling index) expressed its low expression in most of the cases, only few cases expressed strong expression in OKC. Even Low expression of $\mathrm{Ki}-67$ indicates its proliferation potential in odontogenic keratocyst. Ki-67 believed to be a reliable marker of cell proliferation because this non-histone protein is expressed at all stages of cell cycle except G0 and therefore may be taken as a transitional point for progression of disease into malignant lesions.

\section{CONFLICT OF INTEREST}

This study has no conflict of interest to declare by any author.

\section{ACKNOWLEDGEMENT}

I feel great honour and indebtedness in expressing my incessant gratitude to my eminent supervisor Dr. A. H. Nagi, Professor of Morbid Anatomy and Histopathology, UHS, Lahore for his benevolence, constant guidance and keen interest throughout my study period, which enabled me to accomplish the assigned research task. I also express my heartfelt thanks to Dr. Nadia Naseem, Assistant Professor of Morbid Anatomy and Histopathology, UHS, Lahore.

I am also thankful to my lab technologist Sameer Anjum, lab manager Usman Ali and research coordinator Miss Sadia Maqbool without their help and support this could have not been possible.
Copyright $\odot 01$ Oct, 2019.

\section{REFERENCES}

1. Durrani S, Nighat A, Ahmed MR, Khan NUD, Din QU, Sarfaraz T. Histopathological evaluation of odontogenic keratocysts and radicular cysts In Peshawar. Pakistan Oral \& Dental Journal. 2018 Sep 10; 38(2):164-8.

2. Awan MUA, Babar A, Ibrahim MU. Pattern and presentation of odontogenic Jaw cysts: A Clinical Experience. Pak Armed Forces Med J 2017; 67(1):10206

3. Akram S, Naghma, Ali MA, Shakir MM. Prevalence of odontogenic Cysts and Tumors in Karachi, Pakistan. Journal of the Dow University of Health Sciences Karachi 2013, Vol 7 (1): 20-24.

4. Madras J, Lapointe H. Keratocystic odontogenic tumour: Reclassification of the odontogenic keratocyst from cyst to tumour. Journal of the Canadian Dental Association. 2008 Mar 1; 74(2).

5. Scholzen T, Gerdes J. The Ki $\square 67$ protein: from the known and the unknown. Journal of cellular physiology. 2000 Mar; 182(3):311-22.

6. Van Diest PJ, Brugal G, Baak JP. Proliferation markers in tumours: Interpretation and clinical value. Journal of clinical pathology. 1998 Oct; 51(10):716.

7. Gadbail AR, Hande A, Chaudhary M, Nikam A, Gawande M, Patil S, Tekade S, Gondivkar S. Tumor angiogenesis in keratocystic odontogenic tumor assessed by using $C D \square 105$ antigen. Journal of Oral Pathology \& Medicine. 2011 Mar; 40(3):263-9.

8. Selvamani M, Donoghue M, Basandi PS. Analysis of 153 cases of odontogenic cysts in a South Indian sample population: a retrospective study over a decade. Brazilian oral research. 2012 Aug; 26(4):330-4.

9. Ansari SR, Rehman AU, Rehman B. Frequency and Demography of Commonly Occurring Odontogenic cysts in Khyber Pakhtunkhwa (Pakistan). Pakistan Oral \& Dental Journal. 2010 Jun 1; 30(1).

10. Manor E, Kachko L, Puterman MB, Szabo G, Bodner L. Cystic lesions of the jaws-a clinic pathological study of 322 cases and review of the literature. International journal of medical sciences. 2012; 9(1):20.

11. MacDonald-Jankowski DS, Li TK. Orthokeratinized odontogenic cyst in a Hong Kong community: the clinical and radiological features. Dentomaxillofacial Radiology. 2010 May; 39(4):240-5. 
12. Khan M, Din QU, Rehman AU. Clinical and radiological behaviour of sporadic odontogenic keratocyst: A study. Pakistan Oral and Dental Journal. 2009:197-200.

13. Leite TC, Meirelles JR, V. \& Janini, M. E. R. Odontogenic keratocystic tumor: A clinical and histopathologic retrospective study based on the new WHO classification. Int. J. Odontostomat. 2011; 5(3):227-34.

14. Kurdekar RS, Prakash J, Rana AS, Kalra P. Nonsyndromic odontogenic keratocysts: A rare case report. National journal of maxillofacial surgery. 2013 Jan; 4(1):90.

15. Santos LC, Bôas V, Souza D, Oliveira GQ, Ramos EA, Gurgel CA, Santos JN. Histopathological study of radicular cysts diagnosed in a Brazilian population. Brazilian dental journal. 2011; 22(6):449-54.

16. Kwon HI, Lim WB, Kim JS, Ko YJ, Kim IA, Yoon SJ, Choi YD, Choi HR, Kim OJ. Odontogenic keratocyst associated with an ectopic tooth in the maxillary sinus: a report of two cases and a review of the literature. Korean J Pathol. 2011 Jul 1; 45(Suppl 1):S510.

17. Nadalin MR, Fregnani ER, Silva-Sousa YT, Perez DE. Syndecan-1 (CD138) and Ki-67 expression in odontogenic cystic lesions. Brazilian dental journal. $2011 ; 22(3): 223-9$.
18. Wahba OM, Raghib AM, Megahed EM, Hussein MM. Expression of perlecan, syndecan-1 and Ki-67 in keratocystic odontogenic tumor. Tanta Dental Journal. 2013 Dec 1; 10(3):153-9.

19. Humayun S, Prasad VR. Expression of p53 protein and ki-67 antigen in oral premalignant lesions and oral squamous cell carcinomas: An immunohistochemical study. National journal of maxillofacial surgery. 2011 Jan; 2(1):38.

20. Acharya S, Arnold D, Prabhu P, Niranjan KC, Hallikeri $\mathrm{K}$. MCM-2 an alternative to $\mathrm{Ki}-67$ for assessing cell proliferation in odontogenic pathologies. Journal of Oral and Maxillofacial Surgery, Medicine, and Pathology. 2019 Jan $1 ; 31(1): 52-8$.

21. Soluk-Tekkeşin M, Wright JM. The world health organization classification of odontogenic lesions: A summary of the changes of the 2017 (4th) Edition. Turkish Journal of Pathology. 2018 Jan 1; 34(1).

22. Zhai J, Zhang H, Zhang J, Zhang R, Hong Y, Qu J, Chen $\mathrm{F}$, Li T. Effect of the sonic hedgehog inhibitor GDC0449 on an in vitro isogenic cellular model simulating odontogenic keratocysts. International journal of oral science. 2019 Mar; 11(1).

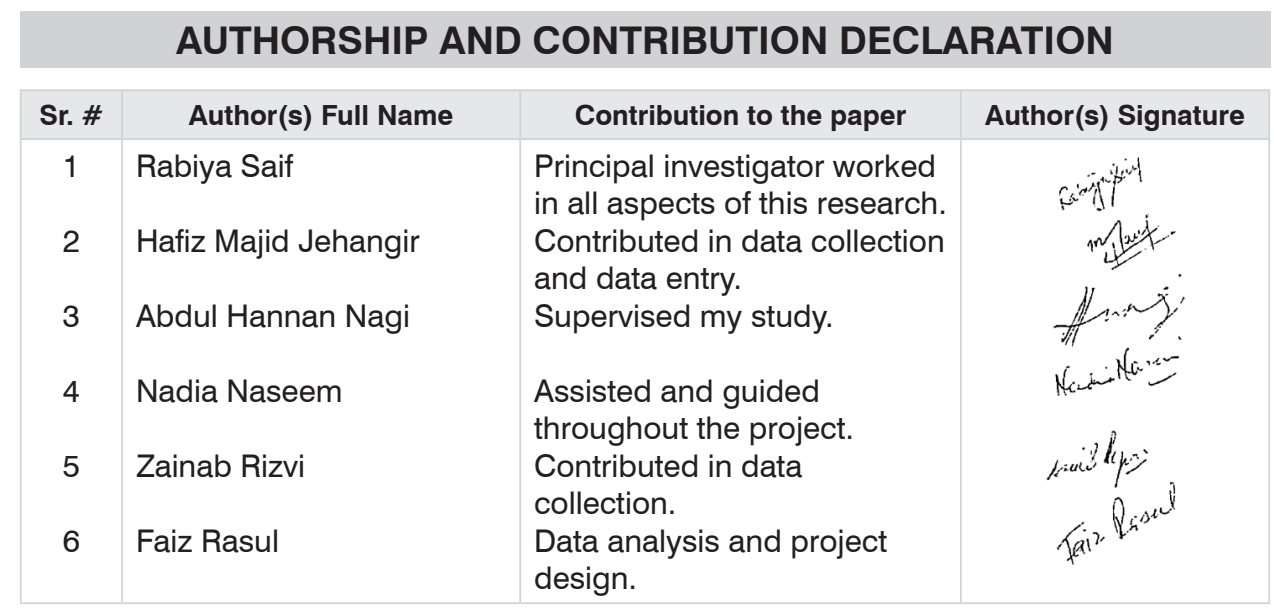

